\title{
Difference in coagulation markers in acute and one year post acute ischemic stroke
}

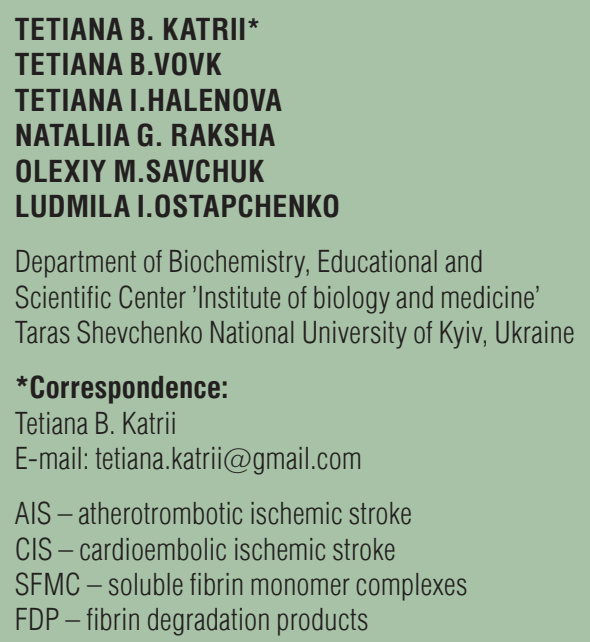

Department of Biochemistry, Educational and Scientific Center 'Institute of biology and medicine' Taras Shevchenko National University of Kyiv, Ukraine

*Correspondence:

Tetiana B. Katrii

E-mail: tetiana.katrii@gmail.com

AIS - atherotrombotic ischemic stroke CIS - cardioembolic ischemic stroke SFMC - soluble fibrin monomer complexes FDP - fibrin degradation products

Keywords: ischemic stroke; hemostasis system; vitamin K-dependent proteins; proteins with prothrombin origin; soluble fibrin monomer complexes.
Received May 27, 2017. Revised July 11, 2017. Accepted July 30, 2017.

\begin{abstract}
Background and purpose: Shifts of the balance between coagulation and fibrinolysis play a crucial role in pathogenesis of cerebral ischemia. However, its relevance to post-acute disease period requires further elucidation. This study aimed to characterize whether hypercoagulation markers differ for patients in acute and the same patients in the post acute phase of ischemic stroke.
\end{abstract}

Materials and methods: Systemic generation of hemostasis markers was monitored and fraction composition was described during one year of disease development and treatment.

Results: Increased concentration of the markers of hypercoagulation in blood plasma of patients in acute as well as one year past acute phase ischemic stroke were shown. Thus, not all markers of hypercoagulation become relevant to norm one year past ischemic stroke. It's the first time characterization of the coagulation markers in acute and post acute period of the absolutely same group of patients was done. Our study demonstrates the difference in quantity and quality of the fractions of proteins with prothrombin origin and soluble fibrin monomer complexes which could be used as a potential target for the prevention of the stroke repetition.

Conclusions: We assume that prothrombin plays the most important role in the development of pathology tested; hence it may provide future targets for therapeutic strategies.

\section{INTRODUCTION}

$\mathrm{T}$ he Global Burden of Disease Study estimated that almost 30\% of all deaths were recorded after stroke attack $(1,2)$. Stroke is the consequence of an interruption to the blood flow to the brain. The most common cause of a stroke is an atherosclerosis, but it can also be caused by a hemorrhage $(3,4)$. Thus, we can conclude that stroke is a widespread disease with high mortality and handicap among survivors (5). Moreover, post stroke disability has been the subject of discussion in the literature ( 6 ). The fact about involving of blood coagulation factors in the initiation of vascular complications is commonly known (7). The monitoring of the hemostasis system is the basic approach for the clinic of cardiovascular diseases, including prevention, acute phase, the process of treatment and post disease period (8-10). Hemostasis factors act as coagulation triggers of cerebrovascular events. Numerous epidemiological studies confirmed the connection between certain factors of blood clotting and the risk of arterial thrombosis. Today fibrinogen is considered as a marker of vascular complications in patients with atherosclerosis (11-13). It was noted that the risk of cardiovascular events 
is more related to the higher concentration of the fibrinogen than to the higher level of cholesterol (14). Fibrinogen level reflects the risk of a stroke (16). But some researchers have provided controversial evidence regarding the association between level of plasma fibrinogen and stroke risk (15), especially in the presence of a thickening of the inner and middle walls of the carotid arteries (17). In this framework, additional characterization of fibrinogen is necessary, especially in stroke condition. It is known that the main biological function of fibrinogen is an ability to convert into an active form of fibrin under the thrombin impact followed by avtivation of prothrombin - an origin of thrombin. A number of macromolecular derivatives of fibrinogen and soluble fibrin in high concentration exist in the blood plasma during the hemostasis disorders. These derivatives are soluble fibrin monomer complexes (SFMC) with the products of the cleavage of fibrinogen/ fibrin, which is not transformed into fibrin under the thrombin action $(18,19)$. Thus, during the conversion of fibrinogen to fibrin, thrombin mediates the cleavage of a pair of fibrinopeptide A peptides and produces fibrin monomer, which rapidly polymerizes to form insoluble fibrin clots. Fibrin monomer molecules can circulate in blood plasma and form soluble complexes with fibrinogen molecules in the presence of a sufficient concentration of the latter and a variable amount of cross-linking induced dye FIIIa $(22,23)$. Plasmas degradation of cross-linked fibrin forms a heterogeneous group of degradation products, reactive in assays for D-dimmer (26). Elevated levels of these complexes formed in the activated state of blood coagulation accompanied by the deep vein thrombosis syndrome, disseminated intravascular coagulation, abdominal aortic aneurysm, pneumonia associated with systemic inflammatory response syndrome and coagulopathy, tumor growth, sickle cell anemia $(20,21,25)$. Numerous results indicated that fibrin-related products appear to be a useful diagnostic molecular marker to assess the activity of the coagulation system (21) and showed a distinct entity reflecting thrombin activity in patients with a variety of diseases in early stage (23-25). According to the lot of references, the diagnostic performance of measurement of the elevated level of D-dimer and SFM complexes is comparable, though the last one might be more sensitive and more specific for the diagnosis without a high negative predictive value (26). Thus, SFC is a more accurate and primary indicator than $\mathrm{D}$-dimmer in distinguishing patients with coagulation disorders $(27,28)$. Serial monitoring of SFMC levels in blood plasma may be a value in evaluating the response to therapy and possibly in identifying at-risk patients $(26,28)$.

Given the above, detailed and thorough investigation of the indicator of early thrombogenic conditions such as SFMC as well as a pool of prothrombin origin molecules peptide pool formed in the bloodstream after suffering a stroke, has utmost importance. As we are interested in the timing of disease recurrence, it makes sense to pay atten- tion to the difference of current parameters in acute stroke patients and one year past acute phase stroke patients. It was basis a foundation and purpose of the current work.

\section{MATERIALS AND METHODS}

Ethics statement. The study protocol was approved by the committee from ESC „Institute of biology and medicine", Ukraine, and conforms to the principles outlined in the Declaration of Helsinki. All donors and patients or their relatives had been warned about the conduct of clinical research. Written, informed consent was obtained from all patients.

Groups characterization. Blood plasma samples were taken from 35 healthy donors as well as 66 patients with atherothrombotic ischemic stroke (AIS) and 56 patients with cardioembolic ischemic stroke (CIS) during the acute phase of disease; 56 patients with AIS and $56 \mathrm{pa}-$ tients with CIS one year past acute phase. Patients were hospitalized in the neurological department of the Hospital №4 (Kyiv, Ukraine). The diagnosis of ischemic stroke was confirmed through computed tomography or magnetic resonance imaging. The severity of neurological disorders in patients was assessed on the basis of the National Institute of Health Stroke Scale (NIHSS) scale, USA. According to the severity of the initial neurological deficiency, the patients were divided as follows: with neurological disorders of a mild degree $-18.9 \%$ of patients ( $6.7 \pm 1.1$ points), with an average severity of neurological disorders $-51.9 \%$ of patients $(10.9 \pm 0.8$ points), for $21.4 \%$ of patients severe neurological disorders $(13.9 \pm 0.9$ points) were recorded, and for $7.8 \%$ of patients had too severe neurological deficits (17.1 \pm 0.6 points). On the first day of admission to the hospital, all patients received aspirin $325 \mathrm{mg}$ orally, then $100 \mathrm{mg}$ aspirin daily. Starting from the second day of hospital stay, patients were receiving low molecular weight heparin in prophylactic dose.

Sample collection. Fasting blood samples were collected from the cubital vein of all patients on the $1^{\text {st }}$ day of hospitalization as well as from the same group of patients one year past acute phase of the disease. Thus we obtained two blood samples from each patient: first in the period of stroke aggravation and second - one year after treatment. Blood was collected into 3.8\% sodium citrate (in ration 9:1). Plasma was separated by further centrifugation at $2000 \mathrm{~g}$ for $15 \mathrm{~min}$ at the room temperature and stored at $-20^{\circ} \mathrm{C}$ until experiments were performed. Collective pool of blood plasma of each tested pathologies as well as for healthy donors was prepared for further experiment.

Obtaining of the fraction of the vitamin K-dependent proteins. $1 \mathrm{ml}$ of blood plasma of each tested subtypes of ischemic stroke was continually inc meal mixed with $30 \mathrm{mg}$ of $\mathrm{BaSO}_{4}$ per 1 hour on the ice. The mixture 
was centrifuged at $2000 \mathrm{~g}$ for $15 \mathrm{~min}$. Elution of vitamin $\mathrm{K}$-dependent fractions from the precipitate was done by adding of $50 \mathrm{mM}$ Tris- $\mathrm{HCl}$ buffer, $\mathrm{pH} 7.4$, containing $200 \mathrm{mM} \mathrm{NaCl}$ and $20 \mathrm{mM}$ EDTA (30). The proteins with prothrombin origin content at the separated vitamin $\mathrm{K}$-dependent fractions was measured by standard enzyme linked by immunosorbent assay (ELISA) techniques (31, 32) The ELISA plates were coated overnight at $4^{\circ} \mathrm{C}$ with vitamin $\mathrm{K}$-dependent fractions samples previously diluted 10-fold with $50 \mathrm{mM}$ Tris- $\mathrm{HCl}$ containing $130 \mathrm{mM} \mathrm{NaCl}$, $\mathrm{pH}$ 7.4. After being washed, plates were blocked with 5\% nonfat dry milk in $50 \mathrm{mM}$ Tris- $\mathrm{HCl}$ containing $130 \mathrm{mM}$ $\mathrm{NaCl}, \mathrm{pH} 7.4$ for $1 \mathrm{~h}$ at $37^{\circ} \mathrm{C}$ and washed again. Then the plates were incubated for $1 \mathrm{~h}$ at $37^{\circ} \mathrm{C}$ with rabbit polyclonal antibodies (Shijin International, Mongolia) to prothrombin. Plates were washed and incubated for $1 \mathrm{~h}$ at $37^{\circ} \mathrm{C}$ with corresponding secondary antibodies (Sigma, USA) which were conjugated to horseradish peroxidase. After washing, substrate (o-phenylenediamine and hydrogen peroxide) was added. Plates were read at $492 \mathrm{~nm}$ by a microplate spectrophotometer (Quant TM, BioTek Instruments, Inc, USA).

Obtaining of the fraction of the soluble fibrin monomer complex (SFMC). SFMC were collected from the $1 \mathrm{ml}$ of blood plasma of each tested subtypes of ischemic stroke by incubation with $0.78 \%$ o-phenanthroline per $5 \mathrm{~min}$. The mixture was centrifuged at $2000 \mathrm{~g}$ for 15 min at the room temperature. The precipitate was washed three times by the addition of $0,9 \% \mathrm{NaCI}$ in a volume equal to the initial volume of plasma. The concentration of SFMC was measured through the time record from the moment of the addition of the reagent until the first of the cereals (grains) of fibrin. Accounting was performed up to $150 \mathrm{sec}$. The test was considered positive after materialization of clearly visible in transmitted light flakes or grains, which were noted for the first 150 seconds. The time of the flakes or grain appearance was noted in seconds and concentration was calculated according the calibration chart (33).

Sodium dodecyl sulfate-polyacrylamide gel electrophoresis analysis (SDS-PAGE). Aliquots in volume $50 \mathrm{mkl}$ of each tested fraction of vitamin K-dependent plasma protein as well as soluble fibrin monomer complexes were diluted 10 times by SDS-PAGE sample buffer and applied on $8 \%$ polyacrylamide gel according to Laemmli $(34,35)$. Gels were stained with $0.125 \%$ solution of Coomassie Brilliant Blue G-250 in 25\% isopropanol and $10 \%$ acetic acid.

Western Blot analysis. Following electrophoresis, 10 times diluted aliquots were transferred into Amersham Hybond-C Membrane under standard conditions. Western blot detection was performed using primary polyclonal anti- $\alpha$-FDP antibody (for SFMC fractions aliquots) or polyclonal antibodies to prothrombin (for vitamin $\mathrm{K}$-dependent fractions aliquots) both in the ra- tion 1:2000 (Shijin International, Mongolia). Corresponding secondary antibodies (Sigma, USA) horseradish peroxidase-conjugated antibody in ratio 1: 1500 were detected by 3.3'-diaminobenzidine (DAB) substrate_5 $\mathrm{mg} / \mathrm{ml}$ with $30 \% \mathrm{H}_{2} \mathrm{O}_{2}$.

Chromatographic separation. Size-exclusion chromatography of each tested fractions of vitamin K-dependent plasma protein as well as soluble fibrin monomer complexes were performed. Aliquots in volume $1 \mathrm{ml}$ was applied on Healthcare Life Sciences (HiLoad 16/60 Superdex $200 \mathrm{pg}$ ) column in $50 \mathrm{mM}$ Tris- $\mathrm{HCl}, \mathrm{pH} 7.4$ with the addition of $130 \mathrm{mM} \mathrm{NaCl}$. The column volume was equal $120 \mathrm{ml}$. The stable speed was $1 \mathrm{ml} / \mathrm{min}(36,37)$. A standard ladder with known molecular weight was applied to the column for calibration.

Statistical processing of the results was performed using software Statistica 7 and Origin 9.1. Value changes were considered as significant at $\mathrm{P}<0.05$. Analysis of electrophoregrams was performed by the scanning of the computer program TotalLab 2.01.

\section{RESULTS}

Proteins with prothrombin origin fractions as well as SFMC fraction were obtained from each tested group: healthy donors, patients with acute AIS, acute CIS and the same group of patients one year past AIS or CIS. The concentration of both coagulation markers was determined. We have determined that the concentration of SFMC during the acute atherothrombotic ischemic stroke was $33.4 \pm 15.2 \mathrm{mkg} / \mathrm{ml}$, while maximum concentration $(46.2 \pm 4.1 \mathrm{mkg} / \mathrm{ml})$ was determined in $27 \%$ of patients. For patients with cardioembolic ischemic stroke SFMC was $37.0 \pm 11.8 \mathrm{mkg} / \mathrm{ml}$ and $25 \%$ of patients in this group had elevated level of SFMC $(47.6 \pm 5.3 \mathrm{mkg} / \mathrm{ml})$. One year past average SFMC concentration for patients with AIS was $8.1 \pm 2.6 \mathrm{mkg} / \mathrm{ml}$ and for patients with CIS $14.8 \pm 3.4 \mathrm{mkg} / \mathrm{ml}$. It is important to underline that such concentrations for post stroke fractions were average for all tested past stroke patients without deviations in groups (Table 1).

As known, one of the recently discovered and insufficiently studied risk factors for ischemic stroke development is a production of antibodies directed toward a phospholipid binding protein, in particular to prothrombin. The ability of these antibodies to reduce the functional activity of the target proteins promotes disturbance of pro-and anticoagulant balance. To clarify the characteristics of the blood coagulation system, we measured the total pool of molecules of prothrombin origin. Applying of polyclonal antibodies allowed us to estimate the content of not only prothrombin, but also molecules containing epitopes of prothrombin origin, in particular, intermediates of prothrombin activation, thrombin molecules and their complexes. And so we have determined that the 
Table 1. Characterization of the proteins with prothrombin origin and soluble fibrin monomer complexes concentration in blood plasma of the patient with stroke.

\begin{tabular}{|lccc|}
\hline \multicolumn{2}{|l}{ Tested group of patients } & $\begin{array}{c}\text { Proteins with } \\
\text { prothrombin } \\
\text { origin (units/ml) }\end{array}$ & $\begin{array}{c}\text { SFMC } \\
(\mathrm{mkg} / \mathrm{ml})\end{array}$ \\
\hline $\begin{array}{l}\text { Healthy donors } \\
\begin{array}{l}\text { Patients with the } \\
\text { atherothrombotic } \\
\text { ischemic stroke }\end{array}\end{array}$ Ycute & 0.47 & 2.0 \\
$\begin{array}{l}\text { Patients with the } \\
\text { cardioembolic } \\
\text { ischemic stroke }\end{array}$ & Acute & $0.41 \pm 0.27^{*}$ & $39.8 \pm 1.2^{*}$ \\
\hline
\end{tabular}

* - Statistically significant changes in comparison with the healthy donors, $\mathrm{p}<0.05$

Parameters are expressed as means $\pm \mathrm{SD}$

increase of a pool of prothrombin derivatives occurs in both types of stroke.

Thus, for atherothrombotic ischemic stroke the concentration of the peptides with prothrombin origin was $0.84 \pm 0.27 \mathrm{u} / \mathrm{ml}$, while maximum concentration $(1.036 \pm 0.1$
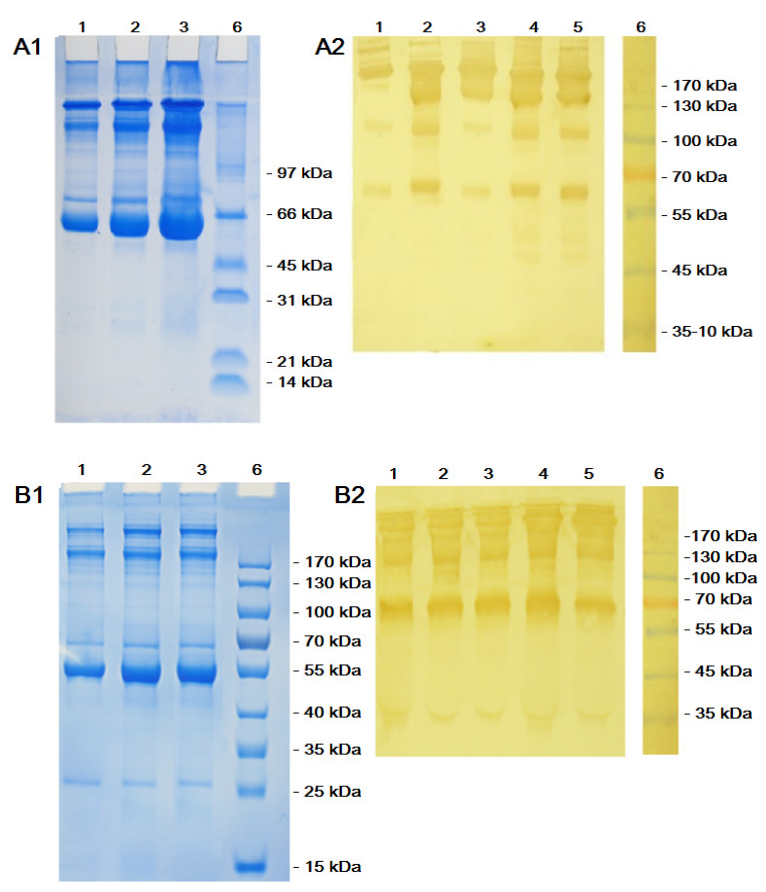

Figure 1. Analysis of the coagulation markers: A. Soluble fibrin monomer complexes fraction; $B$. Proteins with prothrombin origin fraction (A/B1. SDS PAGE image; A/B2. Western Blot image), obtained from blood plasma of: 1. Healthy donors; 2. Patients in acute atherothrombotic ischemic stroke; 3. Patients in acute cardioembolic ischemic stroke; 4. Patients year past acute phase of atherothrombotic ischemic stroke; 5. Patients year past acute phase of cardioembolic ischemic stroke; 6. MW standards The Thermo Scientific PageRule Prestained Protein Ladder, from 10 to $170 \mathrm{kDa}$. $\mathrm{u} / \mathrm{ml}$ ) was detected in $12 \%$ of patients. For patients with cardioembolic ischemic stroke concentration was $0.73 \pm 0.1$ $\mathrm{u} / \mathrm{ml}$ and $21 \%$ of patients in this group had an elevated level of peptides with prothrombin origin $(1.02 \pm 0.1 \mathrm{u} /$ $\mathrm{ml})$. One year post stroke the differentiation inside groups of stroke patients was absent. And for patients with AIS the protein with prothrombin origin fraction concentration was in average $0.47 \pm 0.08 \mathrm{u} / \mathrm{ml}$ and for CIS was $0.43 \pm 0.08 \mathrm{u} / \mathrm{ml}$. (Table 1 ).

Concentrations of both the protein with prothrombin origin as well as SFMC become close to norm one year after ischemic stroke.

At the next step, 8\% SDS-PAGE was performed (Fig. 1).

Results showed the presence of vitamin K-dependent proteins in the blood plasma of both subtypes ischemic stroke in the range from 40 to $250 \mathrm{kDa}$. SDS-PAGE of SFMK showed the presence of protein in the range from 20 to over $330 \mathrm{kDa}$. Fractions with a molecular weight over $330 \mathrm{kDa}$ correspond to SFMC. Additional proteins are the consequence of the cleavage of fibrin/fibrinogen by plasmin in the blood plasma.

Western blot analysis showed that the presented molecules with prothrombin origin in all tested fractions in the range from 30 to $250 \mathrm{kDa}$ were corresponded to prothrombin its degraded forms and complexes (Fig. 1, Table 2).

Protein with $\mathrm{Mr} 70 \pm 5 \mathrm{kDa}$ belongs to prothrombin as well as $37 \mathrm{kDa}$ to thrombin were detected in each tested

Table 2. Western blot analysis of content of the proteins with prothrombin origin fraction in plasma of ischemic stroke patients.

\begin{tabular}{|c|c|c|c|c|c|}
\hline \multirow[t]{2}{*}{$\begin{array}{l}\text { Ladder, } \\
\mathrm{kDa}\end{array}$} & \multirow[t]{2}{*}{$\begin{array}{l}\text { Healthy } \\
\text { donors }\end{array}$} & \multicolumn{2}{|c|}{$\begin{array}{l}\text { Patients with } \\
\text { atherothrombotic } \\
\text { ischemic stroke }\end{array}$} & \multicolumn{2}{|c|}{$\begin{array}{l}\text { Patients with } \\
\text { the cardioembolic } \\
\text { ischemic stroke }\end{array}$} \\
\hline & & $\begin{array}{l}\text { Acute } \\
\text { phase }\end{array}$ & $\begin{array}{l}\text { Year past } \\
\text { acute } \\
\text { phase }\end{array}$ & $\begin{array}{l}\text { Acute } \\
\text { phase }\end{array}$ & $\begin{array}{c}\text { Year past } \\
\text { acute } \\
\text { phase }\end{array}$ \\
\hline 240 & + & + & + & + & + \\
\hline 220 & + & + & + & + & + \\
\hline 200 & + & + & + & + & + \\
\hline 160 & + & + & + & + & + \\
\hline 130 & + & + & + & + & + \\
\hline 118 & + & + & + & + & + \\
\hline 84 & + & + & + & + & + \\
\hline 75 & + & + & + & + & + \\
\hline 50 & + & + & + & + & + \\
\hline 40 & + & + & + & + & + \\
\hline 35 & + & + & + & + & + \\
\hline
\end{tabular}


Table 3. Western blot analysis of content of soluble fibrin monomer complexes fraction in plasma of ischemic stroke patients.

\begin{tabular}{|c|c|c|c|c|c|}
\hline \multirow[t]{2}{*}{$\begin{array}{l}\text { Ladder, } \\
\mathrm{kDa}\end{array}$} & \multirow[t]{2}{*}{$\begin{array}{c}\text { Healthy } \\
\text { donors }\end{array}$} & \multicolumn{2}{|c|}{$\begin{array}{l}\text { Patients with } \\
\text { atherothrombotic } \\
\text { ischemic stroke }\end{array}$} & \multicolumn{2}{|c|}{$\begin{array}{l}\text { Patients with } \\
\text { the cardioembolic } \\
\text { ischemic stroke }\end{array}$} \\
\hline & & $\begin{array}{l}\text { Acute } \\
\text { phase }\end{array}$ & $\begin{array}{c}\text { Year past } \\
\text { acute } \\
\text { phase }\end{array}$ & $\begin{array}{l}\text { Acute } \\
\text { phase }\end{array}$ & $\begin{array}{c}\text { Year past } \\
\text { acute } \\
\text { phase }\end{array}$ \\
\hline$>330$ & + & + & + & + & + \\
\hline 260 & + & + & + & + & + \\
\hline 250 & + & + & + & + & + \\
\hline 220 & + & + & + & + & + \\
\hline 195 & + & + & + & + & + \\
\hline 160 & + & + & + & + & + \\
\hline 130 & + & + & + & + & + \\
\hline 100 & + & + & + & + & + \\
\hline 80 & + & + & + & + & + \\
\hline 60 & + & + & + & + & + \\
\hline 45 & - & + & + & + & + \\
\hline 35 & - & + & + & + & + \\
\hline 25 & - & - & - & + & + \\
\hline 10 & - & - & - & + & + \\
\hline
\end{tabular}

fractions. Mostly, detected proteins were identified in both peptide pool fractions for CIS and AIS patients as well as healthy donors' fractions.

According to the western blot proteins with $\mathrm{Mr}$ from $100 \mathrm{kDa}$ to over $330 \mathrm{kDa}$ in the healthy donors SFMC sample were detected (Fig. 1, Table 3).

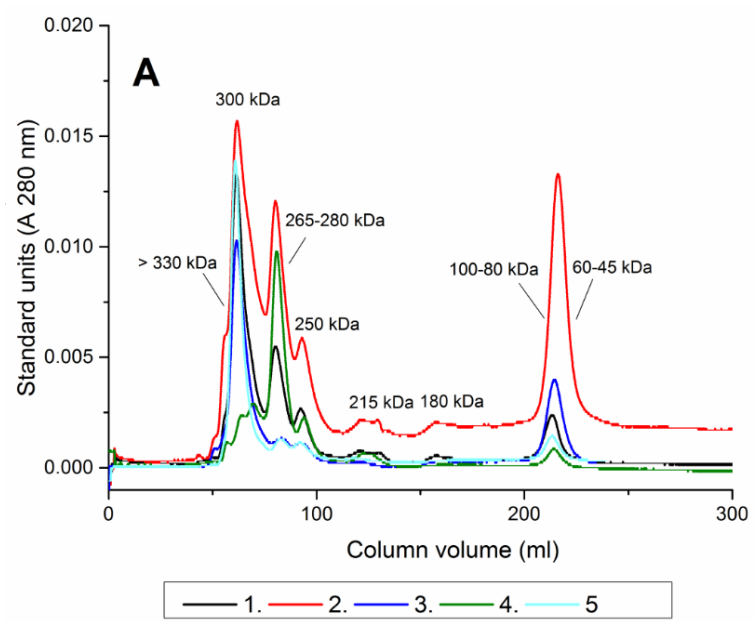

The similar contents were identified in the acute AIS fraction. Acute CIS as well as both year past stroke fraction was characterized by the presence of proteins and their fragments or complexes with $\mathrm{Mr}$ starts from 10 to over $330 \mathrm{kDa}$.

At the next step, the size-exclusion chromatography was performed to characterize the content of tested fractions of vitamin $\mathrm{K}$-dependent plasma proteins as well as SFMC fractions. It was shown that development of ischemic stroke accompanied by the formation of SFMC in the bloodstream could take part in disease complication (Fig. 2).

The results suggest the presence of proteins with $\mathrm{Mr}$ from 45 up to $330 \mathrm{kDa}$. The content of SFMC was similar for all stroke fractions with some exceptions. The difference between results of separation of stroke factions and fractions obtained from healthy donors was obvious. Mostly the protein content of the SFMC fraction is similar for stroke and healthy fractions. But mount of the proteins as mean peaks high is different. (Table 4).

The presence of fragments with a molecular weight about $330 \mathrm{kDa}$ was characteristic for all tested groups. Its elution volume was equal $0.15 \pm 0.02$ pc. of the column volume ( $1 \mathrm{pc}=1$ column volume, in our case it is equal to $120 \mathrm{ml}$ ).

The same situation was inherent for complexes with $\mathrm{Mr}$ from 280 to $250 \mathrm{kDa}$. These fractions were present in the healthy donor's fraction too, but in smaller amounts. In fact, the first three peaks of chromatogram of SFMC are common for all tested fractions and were verified only in their height.

Both acute and one year past AIS SFMC fractions included the complexes with $\mathrm{Mr} 215 \mathrm{kDa}$ and $180 \mathrm{kDa}$. The

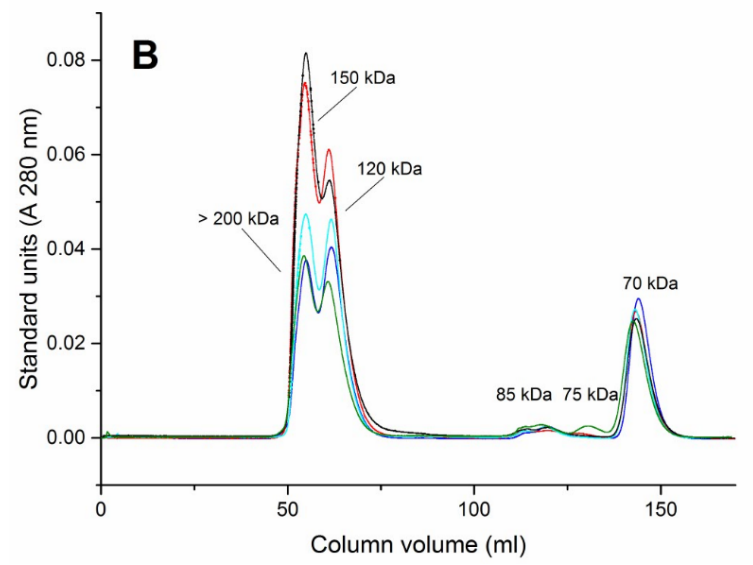

Figure 2. Size-exclusion chromatography separation of: A - Soluble fibrin monomer complexes fraction; $\mathbf{B}$ - Proteins with prothrombin origin fraction; obtained from the blood plasma of: 1. Patients year past acute phase of atherothrombotic ischemic stroke; 2.Patients in acute atherothrombotic ischemic stroke; 4. Healthy donors; 4. Patients year past acute phase of cardioembolic ischemic stroke; 5. Patients with acute cardioembolic ischemic stroke. 
Table 4. Analysis of size-exclusion chromatographic separation of the soluble fibrin monomer complex fraction from blood plasma of ischemic stroke patients.

\begin{tabular}{|c|c|c|c|c|c|}
\hline $\begin{array}{l}\text { Soluble fibrin monomer complex } \\
\text { separated from the blood plasma of }\end{array}$ & $\begin{array}{l}\text { Area under peak } \\
\text { (s.u.) }\end{array}$ & $\begin{array}{l}\text { Peaks quantity } \\
\text { (pc.) }\end{array}$ & $\begin{array}{l}\text { Column volumes } \\
\text { for elution (pc.) }\end{array}$ & $\begin{array}{l}-\mathrm{Mr} \text { of the peaks } \\
\text { content }(\mathrm{kDa})\end{array}$ & $\begin{array}{l}\text { Peak height. } \\
\text { (s.u.) }\end{array}$ \\
\hline \multirow[t]{4}{*}{ Healthy donors } & 0.18918 & 1 & 0.15 & $>300$ & 10.10 \\
\hline & 0.02729 & 2 & 0.23 & 280 & 0.90 \\
\hline & 0.06337 & 3 & 0.24 & 260 & 0.80 \\
\hline & 0.17065 & 4 & 0.51 & $100-45$ & 4.05 \\
\hline \multirow{6}{*}{$\begin{array}{l}\text { Patients with acute atherothrombotic } \\
\text { ischemic stroke }\end{array}$} & 0.29305 & 1 & 0.17 & $330-300$ & 15.50 \\
\hline & 0.13172 & 2 & 0.23 & $265-280$ & 12.53 \\
\hline & 0.09558 & 3 & 0.24 & 250 & 5.70 \\
\hline & 0.07276 & 4 & 0.35 & 215 & 1.75 \\
\hline & 0.0718 & 5 & 0.45 & 180 & 1.73 \\
\hline & 0.51635 & 6 & 0.51 & $100-45$ & 13.00 \\
\hline \multirow{4}{*}{$\begin{array}{l}\text { Patients with acute cardioembolic } \\
\text { ischemic stroke }\end{array}$} & 0.14977 & 1 & 0.17 & 300 & 13.05 \\
\hline & 0.01753 & 2 & 0.23 & 280 & 0.90 \\
\hline & 0.05426 & 3 & 0.24 & 260 & 0.80 \\
\hline & 0.09486 & 4 & 0.51 & $100-45$ & 1.01 \\
\hline \multirow{6}{*}{$\begin{array}{l}\text { Patients with past one year } \\
\text { atherothrombotic ischemic stroke }\end{array}$} & 0.1618 & 1 & 0.17 & 300 & 13.05 \\
\hline & 0.05549 & 2 & 0.23 & $265-280$ & 5.40 \\
\hline & 0.03587 & 3 & 0.24 & 250 & 2.50 \\
\hline & 0.02209 & 4 & 0.35 & 215 & 0.70 \\
\hline & 0.02293 & 5 & 0.45 & 180 & 0.70 \\
\hline & 0.0767 & 6 & 0.51 & $100-45$ & 2.42 \\
\hline \multirow{5}{*}{$\begin{array}{l}\text { Patients with past one year } \\
\text { cardioembolic ischemic stroke }\end{array}$} & 0.06036 & 1 & 0.17 & 300 & 2.80 \\
\hline & 0.08166 & 2 & 0.23 & $265-280$ & 9.50 \\
\hline & 0.0286 & 3 & 0.24 & 260 & 2.10 \\
\hline & 0.01414 & 4 & 0.35 & 215 & 0.60 \\
\hline & 0.03892 & 5 & 0.51 & $100-45$ & 0.70 \\
\hline
\end{tabular}

elution volumes of these proteins were 0.35 and $0.45 \mathrm{pc}$. of the column volume. The height was 1.75 and 1.73 s.u for acute, and 0.7 s.u. for one year past AIS. However, CIS unlike AIS had the same peak just for one year past of disease.

Accordingly, the most widely represented variations peak for AIS. Even a year after stroke soluble fibrin monomer complex content was higher compared to the healthy donors' index. Healthy donors also had some of these complexes, but in trace amounts. For acute CIS situation was similar as for AIS, but past one year it got closer to healthy donors.

Results of chromatographic separation of vitamin Kdependent fractions obtained from the patients with ischemic stroke in acute and post acute phases suggests the presence of proteins with $\mathrm{Mr}$ from 70 to higher $200 \mathrm{kDa}$ (Fig. 2B, Table 5). Most all peaks were presented in each tested fractions. Just the high of peaks had been different for each tested fractions.
Thus the proteins with $\mathrm{Mr}>200 \mathrm{kDa}$ as well as 150 $\mathrm{kDa}$ and $120 \mathrm{kDa}$ were discovered in each fraction included healthy donors' fraction but in different amounts. The highest peak was observed in both AIS fraction in acute and one year past acute ischemic stroke patients. Their heights were equal 7.4 and 8.1 s.u. accordingly. The height of CIS and healthy donors' fractions was $3.6 \pm 0.2$ s.u. The volume of elution of SFMC was $>0.1$ pc. of column volume. We received SFMC in the same peaks with protein with $\mathrm{Mr} 150 \mathrm{kDa}$. The area under this peak was bigger and was equal to $0.45 \pm 0.2$ s.u. in average. Elution volume of protein with $\mathrm{Mr} 150$ $\mathrm{kDa}$ was $0.11 \mathrm{pc}$. And for protein with $\mathrm{Mr} 120 \mathrm{kDa}$ was 0.13 p c. of the column volume. Interesting that protein with $\mathrm{Mr} 75 \mathrm{kDa}$ was found just in the one year past CIS fraction. The elution volume for a $75 \mathrm{kDa}$ protein from post acute CIS fraction was $0.26 \mathrm{kDa}$. Protein with $\mathrm{Mr} 70 \mathrm{kDa}$ was fined in each tested fractions too. The elution volume of this peak was $0.26 \pm 0.2$ pc. Important to say that the highest peak of protein $70 \mathrm{kDa}$ 
Table 5. Analysis of size-exclusion chromatographic separation of the vitamin K-dependent plasma proteins fraction from blood plasma of ischemic stroke patients.

\begin{tabular}{|c|c|c|c|c|c|}
\hline $\begin{array}{l}\text { Proteins with prothrombin origin } \\
\text { separated from the blood plasma of }\end{array}$ & $\begin{array}{l}\text { Area under peak } \\
\text { (s.u.) }\end{array}$ & $\begin{array}{l}\text { Peaks quantity } \\
\text { (pc.) }\end{array}$ & $\begin{array}{l}\text { Column volumes } \\
\text { for elution (pc.) }\end{array}$ & $\begin{array}{l}-\mathrm{Mr} \text { of the peaks } \\
\text { content }(\mathrm{kDa})\end{array}$ & $\begin{array}{l}\text { Peak height. } \\
\text { (s.u.) }\end{array}$ \\
\hline \multirow[t]{4}{*}{ Healthy donors } & 0.23163 & 1 & 0.11 & $>200$ & 3.7 \\
\hline & 0.31798 & 2 & 0.13 & 120 & 4.0 \\
\hline & 0.03592 & 3 & 0.24 & 85 & 0.09 \\
\hline & 0.21266 & 4 & 0.29 & 70 & 3.0 \\
\hline \multirow{4}{*}{$\begin{array}{l}\text { Patients with acute atherothrombotic } \\
\text { ischemic stroke }\end{array}$} & 0.47355 & 1 & 0.11 & $>200$ & 7.4 \\
\hline & 0.44534 & 2 & 0.13 & 120 & 6.0 \\
\hline & 0.0357 & 3 & 0.24 & 85 & 0.08 \\
\hline & 0.19243 & 4 & 0.29 & 70 & 2.3 \\
\hline \multirow{4}{*}{$\begin{array}{l}\text { Patients with acute cardioembolic } \\
\text { ischemic stroke }\end{array}$} & 0.29942 & 1 & 0.11 & $>200$ & 3.5 \\
\hline & 0.32758 & 2 & 0.13 & 120 & 4.9 \\
\hline & 0.02934 & 3 & 0.24 & 85 & 0.09 \\
\hline & 0.18702 & 4 & 0.29 & 70 & 2.3 \\
\hline \multirow{4}{*}{$\begin{array}{l}\text { Patients with past one year } \\
\text { atherothrombotic ischemic stroke }\end{array}$} & 0.54775 & 1 & 0.11 & $>200$ & 8.1 \\
\hline & 0.4079 & 2 & 0.13 & 120 & 5.2 \\
\hline & 0.03625 & 3 & 0.24 & 85 & 0.09 \\
\hline & 0.18709 & 4 & 0.26 & 70 & 2.2 \\
\hline \multirow{5}{*}{$\begin{array}{l}\text { Patients with past one year } \\
\text { cardioembolic ischemic stroke }\end{array}$} & 0.24781 & 1 & 0.11 & $>200$ & 3.8 \\
\hline & 0.25453 & 2 & 0.13 & 120 & 3.1 \\
\hline & 0.03837 & 3 & 0.24 & 85 & 0.1 \\
\hline & 0.01969 & 4 & 0.26 & 75 & 0.1 \\
\hline & 0.18856 & 5 & 0.29 & 70 & 2.1 \\
\hline
\end{tabular}

was observed in healthy donors' fraction $-3.0 \mathrm{~s}$. u. For stroke fraction, the height of this peak was in average $2.2 \pm 0.2$ s.u.

\section{DISCUSSION}

Hemostasis is one of the most complex physiological self-defense systems which ensure blood fluidity, the maintenance of the rheological properties in the physiological ranges and rapidly induces hemostatic plug formation in order to stop or limit bleeding (38). Hemostatic imbalance, due to the influence of both internal and external factors, increases the risk of bleeding or thrombosis. The study of the functional state of prothrombin causes significant interest because of prothrombin's involvement in not only the realization of several physiological reactions, but also because of its interfering in major physiopathological processes, in particular, the regulation of vascular tone, wounds healing, immune response implementation, development of inflammation, tumors, Alzheimer's disease, atherogenesis and others (39-41). Soluble fibrin monomer complexes (SFMC) are the earliest marker of thrombophilia that represents the complexes of monomeric fibrin with fibrinogen or their products of degradation (FDP). Detection of the SFMC, formed due to the activation of blood clotting by thrombin, reveals a pathological process in the early, preclinical stages (42). SFMC levels are not directly affected by therapy with heparin or thrombolytic agents and may contribute to an accurate diagnosis of thrombotic events. The increased soluble fibrin monomer is typical for the development of disseminated intravascular coagulation, autoimmune diseases and thrombophilia (43).

Extrinsic pathway of the clotting process is initiated by tissue factor which forms a complex with plasma protein activated vitamin $\mathrm{K}$-dependent factor VII with $\mathrm{Mr}$ $50 \mathrm{kDa}$. Than activation of another K-dependent factor - factor X take place, which activates the main protein of the blood coagulation thrombin from the two-chain glycoprotein prothrombin with $\mathrm{Mr} 72 \mathrm{kDa}$. One of the regulative anticoagulant here is protein $S$, a single-chain K-dependent glycoprotein with a Mr $84 \mathrm{kDa}$, which of free form functions as a cofactor to Protein C. The protein with corresponded molecular weight were detected in the fraction of vitamin K-dependent factors tested.

The evolution of our knowledge of the physiology of hemostasis has numerous implications for therapy. Defects associated with the pathways of blood coagulation can be assessed with specific tests. In order to estimate the activity of blood coagulation factors, we determined the concentration of tested fractions of prothrombin pool 
as well as SFMC and characterized it component composition.

It is well known that blood coagulation is a complex reaction network that functions to form a fibrin clot that covers the damaged vessel wall and prevents blood loss (44). It should be noted that the generation of thrombin can be confirmed by accumulation in plasma of $\mathrm{N}$ - terminal part of the prothrombin molecule fragment $\mathrm{F} 1+2$ (47), the molecular weight of that is about $40 \mathrm{kDa}$. Physiological activation of prothrombin, except the formation of thrombin, can be accompanied by accumulation of a number of intermediates, some of that possess enzymatic activity (meizothrombin, meizothrombin 1) and the other one belongs to the functionally inactive derivatives (prethrombin 1, 2, fragments 1, 2, 1+2). Protein fractions with a molecular weight about 50 and $37 \mathrm{kDa}$ may consist of prethrombin 1 and 2, which is agreed with literature, according to that, their appearance in the bloodstream serves as an early marker of intravascular coagulation (48). Meizothrombin (about $70 \mathrm{kDa}$ ) is one of the transient intermediates that are produced during the conversion of prothrombin to thrombin in systems composed of factor $\mathrm{Xa}$ and factor $\mathrm{Va}$ that are quantitatively assembled on an anionic phospholipid surface. The presence in blotogram of the proteins with molecular weights about 118, 136, $170 \mathrm{kDa}$ and others could be result of a formation of prothrombin and its derivative complexes with proteins at the term of ischemic stroke progression. For example, the appearance in the bloodstream of thrombin-antithrombin III complexes (molecular weight about $118 \mathrm{kDa}$ ) is regarded as one of the diagnostic criteria for thrombosis development. On the other hand, Mr $118 \mathrm{kDa}$ could belong to high molecular weight kininogen which is a circulating plasma protein. which participates in the initiation of blood coagulation, and in the generation of the vasodilator bradykinin via the Kallikrein-kinin system. It was reported that prothrombin is able to replace high molecular weight kininogen as a cofactor for the specific binding of factor XI to the platelet (44). Other literature data provided the evidence about formations of the stable complexes of thrombin with sodium dodecyl sulfate in the range of 77 and $>450 \mathrm{kDa}$ with proteins secreted by activated platelets which had no catalytic activity (46).

As known thrombin initially cleaves fibrinopeptide $A$ (FPA) and then fibrinopeptide B (FPB) from the A and B chains of fibrinogen, as a result the exposure of new $\mathrm{N}$ termini and causing conformational changes and exposure of polymerization sites take place (49). This generates „fibrin monomer”, a molecule with a strong tendency to polymerize that can be isolated and characterized in vitro only under stringent dissociating conditions to prevent polymerization. Thrombin also activates factor XIII as fibrin is formed, and factor XIIIa rapidly cross-links adjacent $\gamma$ chains in fibrin polymers. Small amounts of fibrin monomer may not be incorporated into growing clot, but rather circulate in the plasma complex with fibrinogen or degradation products (50). The formation of $\gamma$ chain crosslinks in fibrin that are resistant to degradation leads to the formation of unique degradation products that differ from those of fibrinogen. Consequently, soluble products produced with the $\gamma$ chain cross-link intact, and leads to the formation of a large number of polymeric forms of defined structure or thrombin-treated fibrin fragments $X$, $\mathrm{Y}$ and $\mathrm{E}$, or the fibrinogen-derived fragments $\mathrm{X}, \mathrm{Y}, \mathrm{D}$ and $\mathrm{E}$, or the D-dimer. Under physiological conditions, Ddimer is smaller and is in no covalent complex with the $\mathrm{E}$ domain of a fibrin unit from an adjacent strand to form the $\mathrm{DD}(\mathrm{E})$ complex. If proteolysis is stopped in vitro before degradation goes to completion, a heterogeneous group of larger products can be identified. Assays for SFMC as well as fibrin degradation products are important markers for the diagnosis and monitoring of hypercoagulable states and disseminated intravascular coagulation. A lot of authors had discussed the prevalence of the diagnostic potential between SFMC and D-dimer. And most of them inclined to $\operatorname{SFMC}(27,26)$.

Fibrinogen is a $330-\mathrm{kDa}$ soluble plasma protein consisting of three pairs of disulfide-bonded $\alpha-, \beta$-, and $\gamma$ chains were noted in each tested fractions. Fragmentation of fibrinogen occurs upon cleavages within the $\alpha$-chain to release the $\alpha \mathrm{C}$ fragments, thereby producing fragment $\mathrm{X}(260 \mathrm{kDa})$. Further cleavage of fragment X in the $\alpha$-, $\beta$-, and $\gamma$-chains between the two disulfide rings in one half of the molecule produces fragment $\mathrm{Y}(160 \mathrm{kDa})$ and fragment $\mathrm{D}(100 \mathrm{kDa})$. Thus thrombin-treated fibrin fragments were noticed in each tested fractions. Further cleavage of fragment $Y$ produces a second fragment $D$ and fragment $\mathrm{E}(60 \mathrm{kDa})$ which were not noticed in healthy donors and acute AIC fractions.

\section{CONCLUSION}

As known the highest level of repetition belongs to the stroke. The appearance in the bloodstream after a stroke attack of some pathological protein or peptide could be a reason of such repetition. The detailed and advanced characterization of the proteins, especially markers of hypercoagulation and fibrinolysis, in the bloodstream of patients with cardiovascular disorders will help to find the answer to the question about stroke repetition, pathogenesis and treatment.

This fact is an indicator of the normal activation of coagulation of the patients with chronic ischemic stroke, which is a flagman of balance between hemostasis disorders and rehabilitation.

We can assume that prothrombin plays an important role in the pathological process of the ischemic stroke development.

It was proved that o-phenanthroline method of soluble fibrin monomer complexes separation is accompanied by the additional precipitation of fibrinogen and fibrin fragments. 
The presence of fibrin and fibrinogen degradation products in the acute CIS fraction and the absence of these fragments in acute AIS fractions showed the shift in time of the fibrinolysis process for AIS in contrast to the CIS

Acknowledgements: This work was financed by the Ministry of Education, Taras Shevchenko National University of Kyiv, Ukraine (16BF036-01).

Conflict of interest: The authors declare that there is no conflict of interests regarding the publication of this article.

Compliance with Ethical Standards and Ethical approval: All procedures performed in studies involving human participants were in accordance with the ethical standards of the institutional committee and with the 1964 Helsinki declaration and its later amendments or comparable ethical standards. All donors and patients or their relatives had been warned about the conduct of clinical research. Written, informed consent was obtained from all patients.

\section{REFERENCES}

1. GBD 2013 MORTALITY AND CAUSES OF DEATH COLLABORATORS 2015: Global, regional, and national age-sex specific all-cause and cause-specific mortality for 240 causes of death, 1990-2013: a systematic analysis for the Global Burden of Disease Study 2013 Lancet 385(9963): 117-71.

http://dx.doi.org/10.1016/S0140-6736(14)61682-2

2. NICHOLS M, TOWNSEND N, SCARBOROUGH P, RAYNER M, SCARBOROUGH P 2014 Cardiovascular disease in Europe, epidemiological update. Eur Heart J 35: 2950-2959.

3. RUBIN M, DEMAERSCHALK B 2014 The use of telemedicine in the management of acute stroke. Neurosurg Focus 36(1): E4. https://doi.org/10.3171/2013.11.FOCUS13428

4. HOYERT DL, XU J 2012 Deaths: preliminary data for 2011. National vital statistics reports : from the Centers for Disease Control and Prevention, National Center for Health Statistics, National Vital Statistics System 61(6): 1-52.

5. ADAMSON J, BESWICK A, EBRAHIM S 2004 Is stroke the most common cause of disability? Stroke Cerebrovasc Dis. 13: 171-177.

https://doi.org/10.1016/j.jstrokecerebrovasdis.2004.06.003

6. STURM JW, DEWEY HM, DONNAN GA, MACDONELL RA, MCNEIL JJ, THRIFT AG 2002 Handicap After Stroke: How Does It Relate to Disability, Perception of Recovery, and Stroke Subtype? Stroke 33: 762-768.

https://doi.org/10.1161/hs0302.103815

7. Wolfe CD 2000 The impact of stroke. Brit.Med.Bull 56(2): 275 286. https://doi.org/10.1258/0007142001903120

8. WOODWARD M, LOWE G, CAMPBELL D 2005 Associations of Inflammatory and Hemostatic Variables With the Risk of Recurrent Strok Stroke 36: 2143-2147.

9. SAVCHUK OM, KRAVCHENKO NK, BURLOVA-VASYLIEVA MK, MELNYK VS, OSTAPCHENKO LI 2014 Fibrinogen E-fragment - A Cryptic Effector of Platelet Function. Research Journal of Pharmaceutical, Biological and Chemical Sciences 5(4): $187-192$

10. RAKSHA N，BURLOVA-VASYLIEVA M, TORGALO E, SAVCHUK 2014 The appearance of molecules of prothrombin origin in blood upon development of atherothrombotic and cardioembolic ischemic stroke. Bulletin of Taras Shevchenko National University of Kyiv, series "Biology" 3(68): 57-60

11. LOWE GD, RUMLEY A, WHINCUP PH, DANESH J 2002 Hemostatic and rheological variables and risk of cardiovascular disease. Semin Vasc Med 2: 429-440. https://doi.org/10.1055/s-2002-36771

12. MEHTA SR, YUSUF S 2003 Short- and long-term oral antiplatelet therapy in acute coronary syndromes and percutaneous coronary intervention. JACC 41: 79S-88S. https://doi.org/10.1016/S0735-1097(02)02831-0

13. SWAROWSKA M, POLCZAK A, PERA J, KLIMKOWICZMROWIEC A, SLOWIK A, DZIEDZIC T 2014 Hyperfibrinogenemia predicts long-term risk of death after ischemic stroke. J. Thromb. Thrombolysis 38: 517-521.

https://doi.org/10.1007/s11239-014-1122-1

14. MAURIELLO A, SANGIORGI G, FRATONI S, PALMIERI G, BONANNO E, ANEMONA L, SCHWARTZ RS, SPAGNOLI LG 2005 Diffuse and Active Inflammation Occurs in Both Vulnerable and Stable Plaques of the Entire Coronary Tree: A Histopathologic Study of Patients Dying of Acute Myocardial Infarction. JACC 45: 1585-1593. https://doi.org/10.1016/j.jacc.2005.01.054

15. BAKER I, PICKERING J, ELWOOD C, BAYER A, EBRAHIM S 2002 Fibrinogen, viscosity and white blood cell count predict myocardial, but not cerebral infarction: evidence from the Caerphilly and Speedwell cohort. Thromb Haemost 87: 421-425

16. TAKANO M, INAMI S, ISHIBASHI F, OKAMATSU K, SEIMIYA K, OHBA T, SAKAI S, MIZUNO K 2005 Angioscopic follow-up study of coronary ruptured plaques in nonculprit lesions. JACC 45: 652-658.

https://doi.org/10.1016/j.jacc.2004.09.077

17. LEE AJ, MOWBRAY PI, LOWE GD, RUMLEY A, FOWKES GR, ALLAN PL 1998 Blood viscosity and elevated carotid intimamedia thickness in men and women: the Edinburgh Artery Study. Circulation 97: 1467-1473. https://doi.org/10.1161/01.CIR.97.15.1467

18. SAVCHUK OM 2010 Investigation of appearance blood protein - markers haemostatic disbalance in organism. Physics of the alive J 18(1): 132-137

19. BARKAGAN ZS, MOMOT AP 1999 Fundamentals diagnosis of hemostasis. Nyudyamed-BP 213

20. OLDENBURG J, BARTHELS M 2008 Diagnostic of blood coagulation. Hamostaseologie 28(5): 320-334

21. HOSAKA A, MIYATA T, ARAMOTO H, SHIGEMATSU H, NAKAZAWA T, OKAMOTO H, SHIGEMATSU K, NAGAWA H 2005 Clinical implication of plasma level of soluble fibrin monomer-fibrinogen complex in patients with abdominal aortic aneurysm. J. Vasc Surg 42(2): 200-5. https://doi.org/10.1016/j.jvs.2005.03.042

22. GRAEFF H, HAFTER R, VON HUGO R 1979 On soluble fibrinogen-fibrin complexes. Thromb Res 16: 575-6. https://doi.org/10.1016/0049-3848(79)90106-3

23. NAKAHARA K, KAZAHAYA Y, SHINTANI Y, YAMAZUMI K, EGUCHI Y, KOGA S, WADA H, MATSUDA M 2003 Measurement of soluble fibrin monomer-fibrinogen complex in plasmas derived from patients with various underlying clinical situations. Thromb Haemost 89: 832-6

24. SUZUKI A, EBINUMA H, MATSUO M, MIYAZAKI O, YAGO H 2007 The monoclonal antibody that recognizes an epitope in the $\mathrm{C}$-terminal region of the fibrinogen alpha-chain reacts with soluble fibrin and fibrin monomer generated by thrombin but not with those formed as plasmin degradation products. Thromb Res 121(3):377-85. https://doi.org/10.1016/j.thromres.2007.05.008

25. KOGA SA 2004 novel molecular marker for thrombus formation and life prognosis--clinical usefulness of measurement of solu- 
ble fibrin monomer-fibrinogen complex (SF). Rinsho Byori 52(4): 355-61

26. HORAN JT, FRANCIS CW 2001 Fibrin degradation products, fibrin monomer and soluble fibrin in disseminated intravascular coagulation. Semin Thromb Hemost 27(6): 657-66. https://doi.org/10.1055/s-2001-18870

27. SINGH N, PATI HP, TYAGI S, UPADHYAY AD, SAXENA R 2015 Evaluation of the Diagnostic Performance of Fibrin Monomer in Comparison to d-Dimer in Patients With Overt and Nonovert Disseminated Intravascular Coagulation. Clin Appl Thromb Hemost "in press"

28. PARK KJ, KWON EH, KIM HJ, KIM SH 2011 Evaluation of the diagnostic performance of fibrin monomer in disseminated intravascular coagulation. Korean J Lab Med 31(3): 143-7. https://doi.org/10.3343/kjlm.2011.31.3.143

29. MISAKI T, KITAJIMA I, KABATA T, TANI M, KABATA C, TSUBOKAWA T, ASAKURA H, TOMITA K 2008 Changes of the soluble fibrin monomer complex level during the preoperative period of hip replacement surgery. J Orthop Sci 13(5): 419-424

30. RAKSHA N, BURLOVA-VASYLIEVA M, TORGALO E, SAVCHUK O 2014 The appearance of molecules of prothrombin origin in blood upon development of atherothrombotic and cardioembolic ischemic stroke. Bulletin of Taras Shevchenko National University of Kyiv, series Biology 3(68): 57-60. Ukrainian

31. HOCKFIELD S, CARLSON S, EVANS C 1993 Selected methods for antibody and nucleic acid probes 4(1): 679

32. KEMENY M 1991 A Practical Guide to ELISA. NY: Pergamon Press $178 \mathrm{p}$

33. MOMOT A, LAKOMOV V, BARKAGAN S 1996 Methodology and clinical significance of paracoagulation phenantroline test. The wedge laboratory diagnosis 4: 17-20. Ukrainian

34. CLEVELAND D, FISCHER S, Kirschner M, Laemmli UK 1977 Peptide mapping by limited proteolysis in sodium dodecyl sulfate and analysis by gel electrophoresis. Journal of Biological Chemistry 252(3): 1102-1106

35. WEBER K, OSBORN M 1969 The reliability of molecular weight determinations by dodecyl sulfate-polyacriylamide gel electrophoresis. The Journal of Biological Chemistry 244(16): 4406-4412

36. KATRII T, VOVK T, KRAVCHENKO N, SAVCHUK O 2015 The level of IgG and ADP-inducible platelet aggregation in patients with systemic lupus erythematosus and different subtypes of ischemic stroke. Bulletin of Taras Shevchenko National University of Kyiv, series Biology 1(18): 43-45

37. HUA Y, JIANG B, MINE Y, MU W 2008 Purification and characterization of a novel fibrinolytic enzyme from Bacillus sp. nov. SK006 isolated from an Asian traditional fermented shrimp paste. J. Agric. Food Chem 56: 1451-1457. https://doi.org/10.1021/jf0713410

38. STASSEN J, ARNOUT J, DECKMYN H 2004 The hemostatic system. Curr.Med.Chem 11(17): 2245-2260. https://doi.org/10.2174/0929867043364603
39. ALEMAN M, WALTON B, BYRNES J 2013 Elevated prothrombin promotes venous, but not arterial, thrombosis in mice. Arterioscler Thromb Vasc Biol 33(8): 1829-1836. https://doi.org/10.1161/ATVBAHA.113.301607

40. WOLBERG AS, MONROE DM, ROBERTS HR, HOFFMAN M 2003 Elevated prothrombin results in clots with an altered fiber structure: a possible mechanism of the increased thrombotic risk. Blood 101: 3008-3013.

https://doi.org/10.1182/blood-2002-08-2527

41. CASTOLDI E, SIMIONI P, TORMENE D, THOMASSEN MC, SPIEZIA L, GAVASSO S, ROSING J 2007 Differential effects of high prothrombin levels on thrombin generation depending on the cause of the hyperprothrombinemia. J Thromb Haemost 5: 971-979. https://doi.org/10.1111/j.1538-7836.2007.02448.x

42. HETLAND O, KNUDSEN A, DICKSTEIN K, NILSEN DW 2002 Characteristics and prognostic impact of plasma fibrin monomer (soluble fibrin) in patients with coronary artery disease. Blood Coagul Fibrinolysis 13(4): 301-308. https://doi.org/10.1097/00001721-200206000-00005

43. IEKO M, NAITO S, YOSHIDA M, KANAZAWA K, MIZUKAMI K, SATO H, YUI T, NAKABAYASHI T, HIRABAYASHI T, OGUMA Y. TOHOKU 2009 Plasma soluble fibrin monomer complex as a marker of coronary thrombotic events in patients with acute myocardial infarction. J Exp Med 219(1): 25-31

44. HOFFMAN M, MONROE DM 2007 Coagulation 2006: a modern view of hemostasis. Hematol Oncol Clin North Am 21: 1-11. https://doi.org/10.1016/j.hoc.2006.11.004

45. HO D, BADELLINO K, BAGLIA F, SUN M 2000 The Role of High Molecular Weight Kininogen and Prothrombin as Cofactors in the Binding of Factor XI A3 Domain to the Platelet Surface. The Journal of Biological Chemistry 275: 25139-25145. https://doi.org/10.1074/jbc.M001890200

46. BROWNE P, MILLER J, DETWILER T 1988 Kinetics of the formation of thrombin-thrombospondin complexes: Involvement of a $77-\mathrm{kDa}$ intermediate. Archives of Biochemistry and Biophysics 265(2): 534-538. https://doi.org/10.1016/0003-9861(88)90158-0

47. JUUTISTENAHO $S$, VAHTERA E, ARANKO K, KEKOMÄKI R 2010 Prothrombin activation fragment $1+2$ as a marker of coagulation activation in cord blood collection for banking. Transfus. Med 20(4): 250-257.

https://doi.org/10.1111/j.1365-3148.2010.01004.x

48. VOLKOV G, PLATONOV T, SAVCHUK O, KRASRUFF E, CHERNYSHENKO T, GORNITSKAYA O 2005 Modern views on the haemostasis system. Ukraine: Naukova Dumka p.249

49. BUDZYNSKI AZ, OLEXA SA, PANDYA BV 1983 Fibrinogen polymerization site in fibrinogen and fibrin fragment. Ann N Y Acad Sci 408: 301-14. https://doi.org/10.1111/j.1749-6632.1983.tb23253.x

50. SASAKI T, PAGE IH, SHAINOFF JR 1966 Soluble complex of fibrinogen and fibrin. Science 152: 1069-1071. https://doi.org/10.1126/science.152.3725.1069 